\title{
RESEARCH PAPER \\ Agronomic performance and strategies of promoting Quinoa (Chenopodium quinoa Willd) in Malawi
}

\author{
Moses F.A. Maliro, and Allena Laura Njala \\ Lilongwe University of Agriculture and Natural Resources (LUANAR), Crop and Soil Sciences \\ Department. P.O. Box 219, Lilongwe, Malawi.
}

\begin{abstract}
M.F.A. Maliro, and A.L. Njala. 2019. Agronomic performance and strategies of promoting Quinoa (Chenopodium quinoa Willd) in Malawi. Cien. Inv. Agr. 46(2): 82-99. Quinoa (Chenopodium quinoa Willd) has the potential to contribute to Malawi's food and nutritional security by adaptation to droughts that have become frequent due to climate change. Eleven genotypes of quinoa were introduced in 2012 and evaluated for plant growth and yield performance in different environments of central and southern regions of Malawi to determine the potential for quinoa production in the country. The first trials were conducted at Bunda in Lilongwe and Bembeke in Dedza in 2012 under irrigated conditions. Trials under rainfed conditions were conducted at the Bunda site in the 2012/13 and 2014/15 cropping seasons. Evaluation of thirteen promising genotypes under irrigated conditions (2014 to 2015) was extended to six extension planning areas, including Chiluwa in Salima and Nkhunga (Nkhotakota) as warm environments, Mwansambo (Nkhotakota) as a mildly warm environment, Malomo (Ntchisi) as a mildly cool environment, and Kalira 2 (Ntchisi) and Nalunga (Dowa) as cool environments. The genotypes were laid out in completely randomized block designs with four replicates. The maturity period of the genotypes was early in the warm sites ( 88 days in Nkhunga and 94 days in Chiluwa) and delayed in the cooler sites (121 days in Nalunga and 120 days in Kalira). On the basis of genotype and site-specific results, the highest grain yields were achieved for Brightest Brilliant Rainbow (BBR) (3,992 $\left.\mathrm{kg} \mathrm{ha}^{-1}\right)$, QQ74 (3,652 kg ha-1), Black Seeded (3,426 kg ha-1), Multi-Hued (3,272 $\left.\mathrm{kg} \mathrm{ha}^{-1}\right)$ and Puno $\left(3,251 \mathrm{~kg} \mathrm{ha}^{-1}\right)$ in Nalunga and in QQ74 (4,311 kg ha-1), BBR (3,331 kg ha-1), Multi-Hued $\left(3,184 \mathrm{~kg} \mathrm{ha}^{-1}\right)$ and Cherry Vanilla $\left(3,056 \mathrm{~kg} \mathrm{ha}^{-1}\right)$ in Malomo. The lowest yields obtained were from Cherry Vanilla, Red Head $\left(1,276 \mathrm{~kg} \mathrm{ha}^{-1}\right)$ and BBR $\left(1,255 \mathrm{~kg} \mathrm{ha}^{-1}\right)$ in Chiluwa. Quinoa production is possible in Malawi. The genotypes QQ74, BBR, Multi-Hued, Cherry Vanilla, Bio-Bio, Titicaca and Black Seeded have been released for commercial production. Engagement of both government and nongovernmental organizations with a focus on seed systems, processing and utilization can help to integrate quinoa into the food systems of Malawi.
\end{abstract}

Keywords: Adaptation, farmers, irrigated conditions, rainfed conditions, quinoa.

Received Mar 06, 2019. Accepted Jun 04, 2019.

Corresponding author: mmaliro@hotmail.com; mmaliro@luanar.ac.mw 


\section{Introduction}

\section{Quinoa and its importance}

Quinoa (Chenopodium quinoa Willd.) is an emerging important food crop in the world. It is regarded as a pseudo cereal because it is dicotyledonous rather than monocotyledonous like true cereals. It originated from the Andean region of Peru, Bolivia, Ecuador, Colombia and Chile, where it was domesticated 5000 to 7,000 years ago for human consumption (Garcia, 2003). The crop was a staple food of the Inca Empire for many centuries (Schlick and Bubenheim, 1993) and is more nutritious than cereals, which are staple food crops in most regions of the world.

Quinoa is gaining global importance due to its excellent protein quality and tolerance to abiotic stresses. Quinoa has been recognized as a highly nutritious crop (Jacobsen and Mujica, 2003; Wu et $a l ., 2016$ ), and the demand for quinoa has soared in recent years in developed countries, where there is more consciousness about wellness through healthy diets. The seed of quinoa is high in protein, possesses a more balanced amino acid profile compared to that of common cereal grains (Tables 1 and 2) and is gluten free (Oelke et al., 1992; Wu et al., 2014). The increasing popularity of quinoa has triggered intensive breeding, agronomic and food science research. To promote its production and meet the growing market demand, there are also investigations of processing characteristics and market class opportunities (Aluwi et al., 2016; Kowalski et al. 2016).

Quinoa has the capability to grow in a wide range of climatic conditions (Garcia, 2003). There is an excellent potential for successfully growing quinoa where environmental conditions are similar to those of the Andean region (Jacobsen and Mujica, 2003). Quinoa's wide genetic diversity has led to its agronomic versatility and adaptation to different soil types, particularly saline soils, and to environments with extremely variable conditions in terms of humidity, altitude, and temperature (Adams et al., 2001; Betero et al., 2004; Choukar et al., 2016). In areas where frost occurs, quinoa can survive night frost $\left(-8^{\circ} \mathrm{C}\right.$ for 2 to 4 hours) (Jacobsen et al., 2007). Quinoa has been reported to have high salt tolerance (Adolf et al., 2012; Peterson and Murphy, 2015a; Ruiz et al., 2016) and can grow under extremely dry conditions (Sun et al., 2014; Walters et al., 2016), including in drought-prone areas of Africa (Jacobsen et al., 2003).

Table 1. Macronutrient contents of quinoa and selected cereal foods, per 100 grams of dry weight (Source: Koziol, 1992).

\begin{tabular}{lccccc}
\hline Nutrient & Quinoa & Beans & Maize & Rice & Wheat \\
\hline Energy $\left(\mathrm{Kcal} \mathrm{100g}^{-1}\right)$ & 399 & 367 & 408 & 372 & 392 \\
Protein $\left({\left.\mathrm{g} 100 \mathrm{~g}^{-1}\right)}^{\text {Fat }\left(\mathrm{g} 100 \mathrm{~g}^{-1}\right)}\right.$ & 16.5 & 28.0 & 10.2 & 7.6 & 14.3 \\
Total Carbohydrates $\left({\left.\mathrm{g} 100 \mathrm{~g}^{-1}\right)}^{6.3}\right.$ & 1.1 & 4.7 & 2.2 & 2.3 \\
\hline
\end{tabular}

Table 2. Comparison of the essential amino acid properties of quinoa and other selected crop species with the FAO recommended amino acid scoring pattern for 3 - to 10 -year-olds ( $100 \mathrm{~g}^{-1}$ protein).

\begin{tabular}{llllll}
\hline Amino acid & $\mathrm{FAO}^{\dagger}$ & Quinoa $^{\ddagger}$ & Maize & Rice $^{\ddagger}$ & Wheat $^{\ddagger}$ \\
\hline Isoleucine & 3.0 & 4.9 & 4.0 & 4.1 & 4.2 \\
Leucine & 6.1 & 6.6 & 12.5 & 8.2 & 6.8 \\
Lysine & 4.8 & 6.0 & 2.9 & 3.8 & 2.6 \\
Methionine & 2.3 & 5.3 & 4.0 & 3.6 & 3.7 \\
Phenylalanine & 4.1 & 6.9 & 8.6 & 10.5 & 8.2 \\
Threonine & 2.5 & 3.7 & 3.8 & 3.8 & 2.8 \\
Tryptophan & 0.66 & 0.9 & 0.7 & 1.1 & 1.2 \\
Valine & 4.0 & 4.5 & 5.0 & 6.1 & 4.4 \\
\hline
\end{tabular}

$\dagger$ Amino acid scoring pattern for 3- to 10-year-old children, adapted from FAO (2012). Dietary protein quality evaluation in human nutrition, Report of an FAO Expert Consultation, Rome. $\$$ Koziol (1992); §Methionine + cysteine; PPhenylalanine + tyrosine. 
Quinoa cultivation has transcended continental boundaries such that it is now grown in several European countries, including France, England, Sweden, Denmark, Holland and Italy, as well as in China, India, Pakistan, New Zealand, Australia, Canada and the USA, among many others (Bazile et al., 2016; Jacobsen, 2003; Jacobsen and Stolen, 1993; Peterson and Murphy, 2014; Peterson and Murphy, 2015b).

In developing countries, particularly in Africa, the introduction of high yielding, domestically grown quinoa into the diet has the potential to contribute to food and nutritional security (AAFRD, 2005; Babatunde et al., 2011). With the growing demand for quinoa grain in the USA, Europe and Asia, the crop is a potentially innovative and economically promising export crop for many African countries such as Malawi (Jayne et al., 2003). The potential for the successful introduction of quinoa into African farming systems is high, as the crop is adapted to a wide range of climates and ecological zones in the Andean region where it originates. Therefore, Africa can take advantage of the growing world demand to produce quinoa for export in addition to contributing to its own food security.

Background of quinoa studies in Africa and Malawi

Quinoa was relatively obscure in the rest of the world until the UN and FAO declared 2013 as an international year of quinoa to promote its introduction in regions that are challenged by food and nutritional insecurity (UN, 2012). Since then, there have been introductions of quinoa for adaptability studies in several countries outside the Andean region, including Africa. The first quinoa studies on the continent of Africa were conducted in the late 1990s in Kenya and Ethiopia (Oyoo et al., 2010). In 2012, the Lilongwe University of Agriculture and Natural Resources (LUANAR), in collaboration with Washington State University, introduced 13 varieties and genotypes and commenced adaptability studies in Malawi.

The introduction of quinoa to Malawi was prompted by the potential contribution that the crop could make to improve the overall sustainable intensification of agriculture in Malawi (Maliro and Guwela, 2015). Identification of optimally adapted varieties of quinoa to different rainfed and irrigated environments in Malawi would provide an opportunity for further breeding and selection, production and consumption of quinoa in similar target environments (Maliro and Guwela, 2015; Murphy et al., 2016; Peterson et al., 2015).

\section{Justification for quinoa studies in Malawi}

Quinoa has the potential to contribute to Malawi's food and nutritional security. This crop species has wide climatic adaptation and is therefore a potential crop for mitigating climate change impacts (in drought-prone areas) in the country. With the growing demand for quinoa grain, especially in developed countries, this crop species can contribute to farmers' incomes from exports and domestic markets.

The main objective of this study was to introduce quinoa cultivation to Malawi and to evaluate diverse quinoa varieties for plant growth and grain yield performance in different environments of Malawi. The genotypes were evaluated under irrigated conditions for all selected environments in the central region of Malawi and under both irrigated and rainfed conditions at the Bunda site. The specific objectives were 1) to determine the potential for growing quinoa in Malawi environments, 2) to identify varieties with high yields and valuable agronomic characteristics in varying environments, and 3) to test for genotype $\times$ environment interactions that could provide more information to breeders with the goal of developing new varieties for Malawi farmers. 


\section{Materials and Methods}

\section{Quinoa germplasm}

Thirteen (13) genotypes that included released varieties and breeding lines from various origins (Table 3) were supplied by the Department of Crop and Soil Sciences of Washington State University (WSU) to the Lilongwe University of Agriculture and Natural Resources (LUANAR) to be evaluated for adaptability studies in Malawi.

\section{Experiments conducted}

Three experimental evaluations of the quinoa genotypes are described and reported in this paper: (i) preliminary evaluation of the genotypes conducted under irrigated conditions at the Bunda and Bembeke locations, (ii) evaluation of the genotypes under rain fed conditions at the Bunda location, and (iii) evaluation of the genotypes in six sites of Dowa, Ntchisi, Nkhotakota and Salima.
Experiment 1: Preliminary evaluation of the quinoa genotypes

This was the first evaluation of quinoa genotypes in Malawi, which also served as an opportunity for the researchers to become acquainted with the crop and its growth and to observe the potential pests and diseases that would significantly affect its growth and yield performance. This evaluation was conducted in replicated experiments at two sites of the Bunda Campus of LUANAR and the Bembeke Agricultural Research Substation in the Dedza district. The Bunda site represented a relatively warm environment, while Bembeke represented a relatively cool environment of central Malawi. The two sites were deliberately selected for the ease of monitoring the new crop by the researchers who were based at Bunda in collaboration with plant protection officers based at Chitedze. The experiments were conducted from June 1 to mid-October 2012 under irrigated conditions.

Eleven (11) of the thirteen (13) genotypes (G1 to G11 described in Table 3) that were supplied

Table 3. A list of quinoa varieties that were introduced and evaluated for adaptability in six different environments of central Malawi.

\begin{tabular}{|c|c|c|c|c|}
\hline Variety & & & Origin & Notes \\
\hline 1 & G1 & Black Seeded & Colorado, USA & $\begin{array}{l}\text { Developed from a cross between Chenopodium } \\
\text { quinoa and Chenopodium berlandieri. Very tall } \\
\text { variety }(>2 \mathrm{~m} \text { tall) }\end{array}$ \\
\hline 2 & G2 & Brightest Brilliant Rainbow & Oregon, USA & Bred by Frank Morton of Wild Garden Seeds \\
\hline 3 & G3 & Bio-Bio & Chile & \\
\hline 4 & G4 & Cherry Vanilla & Oregon, USA & Bred by Frank Morton of Wild Garden Seeds \\
\hline 5 & G5 & Multi-Hued & British Columbia, Canada & \\
\hline 6 & G6 & Red Head & Oregon, USA & Bred by Frank Morton of Wild Garden Seeds \\
\hline 7 & G7 & QQ74 & Chile & Heat-tolerant Chilean landrace \\
\hline 8 & G8 & Puno & Denmark & Bred by Sven-Erik Jacobsen \\
\hline 9 & G9 & Titicaca & Denmark & Bred by Sven-Erik Jacobsen \\
\hline 10 & G10 & Ecuadorian & Ecuador & \\
\hline 11 & G11 & $\begin{array}{c}\text { Inca Red } \\
\text { (Pasankalla) }\end{array}$ & Bolivia & Member of the 'Salares' ecotype of quinoa \\
\hline 12 & G12 & QQ065 & Chile & $\begin{array}{c}\text { From the extremely rainy region of Chile } \\
(>2500 \mathrm{~mm}) \text {, shows high resistance to } \\
\text { postharvest sprouting }\end{array}$ \\
\hline 13 & G13 & Rosa Junin & Peru & \\
\hline
\end{tabular}


had enough seed for an experimental evaluation and were therefore evaluated at both sites. The experiments were laid out in a randomized complete block design (RCBD) with three replicates.

The treatment plots were raised flat beds of 4 $\mathrm{m}^{2}$ area $(2 \mathrm{~m} \times 2 \mathrm{~m})$, with $0.5 \mathrm{~m}$ spacing between plots and $1.0 \mathrm{~m}$ between replicates. Slope was the blocking factor in both sites. The treatment plots were watered to field capacity using watering cans prior to sowing the quinoa seed. Seed quantities of five grams $(5 \mathrm{~g})$ per $4 \mathrm{~m}^{2}$ were sown, giving a seed rate of $12.5 \mathrm{~kg} \mathrm{ha}^{-1}$. The seeds were sown in rows drilled at $0.2 \mathrm{~m}$ apart and at $1.0 \mathrm{~cm}$ depth and were then thinly hand-covered with soil. Seedling emergence occurred within four to five days of sowing. Two weeks after sowing, the seedlings were thinned to one seedling per $0.1 \mathrm{mspacing}$, giving an average plant density of 500,000 plants ha $^{-1}$. Soon after thinning, $75 \mathrm{~kg} \mathrm{ha}^{-1}$ of inorganic fertilizer of 23:21:0 + 4 (N:P:K + S) was applied by the banding method alongside the rows of plants. Another $75 \mathrm{~kg} \mathrm{ha}^{-1}$ of the same fertilizer was applied after four weeks following $100 \%$ flowering of the plants.

Irrigation was provided using 10 liter watering cans at rate of 2.5 liters $\mathrm{m}^{-2}$ applied every two days from sowing to maturity, at which point irrigation was withdrawn to allow plants to dry for harvesting. There was no precipitation at either site during the entire irrigated trial period. The experimental plots were kept weed free throughout the growing season.

Data were collected from a net plot comprising an area of $2.56 \mathrm{~m}^{2}$ (excluding the outer $20 \mathrm{~cm}$ perimeter of the plot). The measured traits included the number of days to maturity, plant height at harvest $(\mathrm{cm})$, panicle length $(\mathrm{cm})$, grain yield $(\mathrm{kg}$ $\left.\mathrm{ha}^{-1}\right)$, seed weight ( $\mathrm{g} / 1000$ seeds) and the harvest index. Harvested seed and biomass per plot were weighed, and the yield per hectare was estimated at $12.5 \%$ moisture content. The temperatures for the two sites and rainfall for the Bunda site were recorded. The data were subjected to two-way analysis of variance, with site and genotype as the two factors used in the analysis using the Genstat statistical package version 17, a VSNI Product). Pearson product-moment correlation (Snedecor and Cochran, 1989) analysis was used to assess the relationship between seed yield and 1000 seed weight. Variety and location treatments were considered fixed effects, and blocks and all interactions with blocks were treated as random effects.

Experiment 2: Quinoa growth and grain yield under rainfed conditions at Bunda

Rainfed experiments with the same experimental design as that in experiment 1 were conducted at the Bunda site from mid-December 2012 to midMarch 2013 and were repeated in the 2013/14 and 2014/15 rainy seasons at the same experimental site but in different plots. Twelve of the genotypes (except QQ065) (Table 3) were evaluated during the 2012/13 rainy season, and then nine genotypes (G1 to G9) were evaluated during the subsequent years. The last four genotypes were dropped from further evaluation due to poor performance and limited seed availability. The experimental design was an RCBD with four replicates. The sizes of the treatment plots, plant spacing, and all agronomic management practices and data collection were the same as those in experiment 1 , except that this evaluation was performed under rainfed conditions.

Experiment 3: Quinoa performance in six different environments of central Malawi

Nine genotypes (G1 to G9 in Table 3) were evaluated for growth and yield performance in six sites of varied altitudes in the central region of Malawi (Table 4). The sites were selected because they were within the impact area of Total Land Care (TLC), the collaborating institution working with farming communities. The environmental characteristics were low altitude and warm (Chiluwa EPA in the Salima district and Nkhunga EPA in the Nkhotakota 
district), medium altitude and mildly warm (Mwansambo EPA in the Nkhotakota district), and high altitude and cold (Nalunga EPA in the Dowa district and Malomo EPA in the Ntchisi district) during the period of the experiments (Figure 1 and Table 4). In each site, two different experimental plots close to water sources for irrigation were selected for the experiments. The experimental plots were hosted by farmers who were willing to host and provide labor for management of the plots under the guidance of field coordinators from TLC. Nine varieties of quinoa (Table 3 ) were evaluated in each experimental plot, laid out in a randomized complete block design (RCBD), from May to August and were repeated from September to November 2014. However, the results reported here are for the data collected from experiments performed from June to September/October.

Prior to implementing the experiments, the field coordinators from TLC were trained on management of the trials and data collection and were therefore responsible for supervising the daily field management and data collection. The data collected included the number of days to flowering and to maturity, plant height and panicle length at physiological maturity/harvest and seed yield. The data were analyzed by analysis of variance. Additive main effects and multiplicative interaction (AMMI), genotype main effects and genotype $\times$ environment interaction (GGE) were employed in the evaluation of genotypes.

\section{Results and Discussion}

\section{Quinoa performance at Bunda and Bembeke}

During the preliminary evaluation, the Bunda site represented a warm site, while Bembeke represented a relatively low temperature site. Temperature is a major environmental factor that affects plant growth (Jenner, 1991).

Plant growth parameters

Plant growth of quinoa genotypes at the two sites varied $(\mathrm{p} \leq 0.001)$,with those at Bembeke maturing earlier (104 days) than those at Bunda (111 days), contrary to the expected performance (Table 5, Figure 1 in the Appendix). Temperatures at Bembeke were lower than at Bunda, and this was expected to slow crop growth and maturity (Jenner, 1991), but in this case, the crop seemingly matured earlier due to water constraints. There was not adequate water to irrigate the plants at Bembeke when the crop advanced to physiological maturity. On the other hand, there was a constant and adequate supply of water to irrigate the plants at Bunda; hence, the irrigation was withdrawn when the plants were observed to have matured.

The genotypes also significantly varied $(\mathrm{p} \leq 0.001)$ in maturity period, especially at the Bunda site, where Ecuadorian and Inca Red (Pasankalla) matured 10 days later than the other genotypes, while at Bembeke, the Inca Red genotype matured nine days later, showing a genotype $\times$ site interaction.

Table 4. Description of locations/environments where multilocational evaluation trials of quinoa were conducted.

\begin{tabular}{lccc}
\hline Environment (E) & Name of Site & Altitude (m.a.s.1.) & $\begin{array}{c}\text { Temperature } \\
\text { (from May to August) }\end{array}$ \\
\hline E1 & Nkhunga EPA (Nkhotakota district) & 503 and 515 & Warm $\left(25-28^{\circ} \mathrm{C}\right)$ \\
E2 & Malomo EPA (Ntchisi district) & 1077 & Cold $\left(18-22^{\circ} \mathrm{C}\right)$ \\
E3 & Chiluwa EPA (Salima district) & 470 and 521 & Warm $\left(25-28^{\circ} \mathrm{C}\right)$ \\
E4 & Nalunga EPA (Dowa district) & 1049 and 1267 & Cold $\left(18-22^{\circ} \mathrm{C}\right)$ \\
E5 & Kalira 2 EPA (Ntchisi district) & 1456 & Cold $\left(16-20^{\circ} \mathrm{C}\right)$ \\
E6 & Mwansambo EPA (Nkhotakota district) & 555 and 617 & Mildly warm $\left(23-25^{\circ} \mathrm{C}\right)$ \\
\hline
\end{tabular}




\section{$\underline{\text { Grain yield parameters }}$}

The negative impact of limited water supply for irrigation at Bembeke compared to Bunda was reflected in most of the plant growth and yield parameters, including the plant height, panicle length and grain yield (Table 5), total aboveground biomass, harvest index and grain yield, with the exception of seed size (in Table 6 and Figure 1 in the Appendix). Where water was adequately available throughout the growing period (at Bunda), the quinoa performed far better, with a mean plant height of $87 \mathrm{~cm}$ versus $47 \mathrm{~cm}$, a mean panicle length of $36 \mathrm{~cm}$ versus $29 \mathrm{~cm}$, and a mean grain yield of $2171 \mathrm{~kg} \mathrm{ha}^{-1}$ versus $388 \mathrm{~kg} \mathrm{ha}^{-1}$, the latter instance of which was achieved at the Bembeke site. These results demonstrate that the availability of adequate water for irrigation of quinoa is still critical for better yield of quinoa, although the crop is known to be drought tolerant. Where there is low water availability, there are still prospects of harvesting some grain. This finding calls for the selection of genotypes of quinoa that are more adapted to low moisture-stressed environments due to limited water supply.

Grain yield also showed significant interaction between genotype and site $(\mathrm{p} \leq 0.001)$, with Brightest Brilliant Rainbow (BBR), Multi-Hued, Cherry Vanilla, QQ74 and Titicaca as the highest yielding genotypes at Bunda. Multi-Hued, Bio-Bio, BBR, Puno, Read Head and Black Seeded being relatively high yielding at Bembeke. Nevertheless, the Bunda grain yields were much higher than those for quinoa at Bembeke.

\section{Performance of quinoa in multiple locations}

\section{Maturity period}

The maturity period of quinoa varied $(\mathrm{p}<0.001)$ among the sites, whereby in the low-altitude sites (Chiluwa EPA in Salima and Nkhunga EPAin Nkhotakota), the quinoa matured early, within 90 days. In the mid-altitude sites (Mwansambo

Table 5. Performance in number of days to maturity, plant height at physiological maturity, panicle length of quinoa genotypes evaluated at Bunda Campus' horticultural research farm (BD) and the Bembeke sub-research station (BK) under irrigated conditions from June to mid-October 2012.

\begin{tabular}{|c|c|c|c|c|c|c|}
\hline \multirow{2}{*}{ Varieties/Lines } & \multicolumn{2}{|c|}{ Days to maturity } & \multicolumn{2}{|c|}{ Plant height $(\mathrm{cm})$} & \multicolumn{2}{|c|}{ Panicle length $(\mathrm{cm})$} \\
\hline & $\mathrm{BD}$ & $\mathrm{BK}$ & $\mathrm{BD}$ & $\mathrm{BK}$ & $\mathrm{BD}$ & $\mathrm{BK}$ \\
\hline Black Seeded & 109 & 103 & 86.0 & 41.3 & 41.33 & 0.48 \\
\hline Multi-Hued & 109 & 103 & 82.7 & 54.7 & 32.00 & 0.27 \\
\hline Bio-Bio & 109 & 103 & 99.3 & 66.0 & 40.00 & 0.20 \\
\hline Brightest BR & 109 & 103 & 96.0 & 63.7 & 30.00 & 0.24 \\
\hline Red Head & 109 & 103 & 88.0 & 41.0 & 37.33 & 0.30 \\
\hline Cherry Vanilla & 109 & 103 & 91.7 & 55.3 & 32.67 & 0.24 \\
\hline Inca Red & 119 & 103 & 72.7 & 36.0 & 27.00 & 0.16 \\
\hline Titicaca & 109 & 103 & 74.0 & 43.3 & 34.67 & 0.32 \\
\hline QQ74 & 109 & 102.3 & 108.3 & 47.0 & 44.33 & 0.50 \\
\hline Puno & 109 & 103 & 64.0 & 41.7 & 31.00 & 0.32 \\
\hline Ecuadorian & 119 & 112 & 90.7 & 21.3 & 40.33 & 0.29 \\
\hline Mean & 110.8 & 103.8 & 86.7 & 46.5 & 35.52 & 0.30 \\
\hline $\operatorname{LSD}(0.05)$ & \multicolumn{2}{|c|}{0.4056} & \multicolumn{2}{|c|}{23.04} & \multicolumn{2}{|c|}{12.710} \\
\hline $\mathrm{CV} \%$ & \multicolumn{2}{|c|}{0.2} & \multicolumn{2}{|c|}{21.0} & \multicolumn{2}{|c|}{23.8} \\
\hline Variety $_{\mathrm{F} \text { Probability }}$ & \multicolumn{2}{|c|}{0.001} & \multicolumn{2}{|c|}{0.002} & \multicolumn{2}{|c|}{0.195} \\
\hline Site $_{\text {F Probability }}$ & \multicolumn{2}{|c|}{0.001} & \multicolumn{2}{|c|}{0.001} & \multicolumn{2}{|c|}{0.002} \\
\hline Variety x Site $_{F \text { Probability }}$ & \multicolumn{2}{|c|}{0.001} & \multicolumn{2}{|c|}{0.147} & \multicolumn{2}{|c|}{0.110} \\
\hline $\mathrm{SE} \pm$ & \multicolumn{2}{|c|}{0.2239} & \multicolumn{2}{|c|}{13.89} & \multicolumn{2}{|c|}{4.847} \\
\hline
\end{tabular}


EPA in Nkhotakota), the quinoa matured in 100 to 110 days, while at high altitude (Nalunga in Dowa, Kalira 2 and Malomo in Ntchisi), it took up to 120 days. No significant variation in the maturity period was observed among the varieties (Table 7, Figures2 and 3 in the Appendix). A similar pattern of results was reflected for panicle length (Figure 1(b) in the Appendix), which also correlated positively with grain yield (Maliro et al., 2017).

The plant height of the quinoa genotypes at the maturity stage was significantly different among sites $(p<0.001)$ but not among genotypes $(p=0.815)$ (Figure 4 in the Appendix), and there were also no site $\mathrm{x}$ genotype interaction effects $(\mathrm{p}=0.068)$. Environmental factors therefore had a significant influence on quinoa plant growth, as reflected in the variation in plant height across the sites. The plants grew tallest in the Mwansambo, Nalunga and Kalira EPAs, followed by Chiluwa and Malomo, while Nkhunga had the shortest plants overall.

The results presented in Figures 5 and 6 (in the Appendix) show that the panicle length of the quinoa plants, as was the case with plant height, significantly varied across the six sites but was not different among the genotypes and had no site $\times$ genotype interaction effects. Panicle length corresponded to plant height where tall quinoa plants had long panicles and short plants also had short panicles. The significance of panicle length was its positive correlation with grain yield. Long panicles also correlated with high grain yields of quinoa (Oyoo et al., 2015).

Grain yields (Table 8, and in Figures 7, 8and9 in the Appendix) varied $(\mathrm{p}<0.001)$ among sites and had significant site variety interactions. The highest yielding varieties were BBR (2669 kg ha $\left.{ }^{-1}\right)$ and Multi-Hued (2018 kg ha-1) in Chiluwa EPA and Cherry Vanilla (4141 kg ha-1 , Multi-Hued (3203 $\mathrm{kg} \mathrm{ha}^{-1}$ ) and Bio-Bio (2630 $\left.\mathrm{kg} \mathrm{ha}^{-1}\right)$ in Nkhunga for the low altitude and warm ecological area. For the mid-altitude area in Mwansambo, Bio-Bio (4290 kg ha-1), Puno (3982 kg ha ${ }^{-1}$ ), QQ74 (3721 $\left.\mathrm{kg} \mathrm{ha}^{-1}\right)$ and Cherry Vanilla (3701 $\left.\mathrm{kg} \mathrm{ha}^{-1}\right)$ had the highest yields. In Nalunga, Cherry Vanilla (4141 $\mathrm{kg} \mathrm{ha}^{-1}$ ), Red Head (3685 $\mathrm{kg} \mathrm{ha}^{-1}$ ) and Multi-Hued (3529 kg ha ${ }^{-1}$ ) had the highest yields; in Kalira 2, the yields of BBR (1302 kg ha-1), Bio-Bio (911 $\mathrm{kg} \mathrm{ha}^{-1}$ ) and Titicaca (911 kg ha-1) were highest,

Table 6: Performance of quinoa genotypes evaluated at Bunda Campus horticultural research farm (BD) and the Bembeke sub-research station (BK) under irrigated conditions from June to mid-October 2012.

\begin{tabular}{|c|c|c|c|c|c|c|c|c|}
\hline \multirow{2}{*}{ Varieties/Lines } & \multicolumn{2}{|c|}{ Biomass $\left(\mathrm{kg} \mathrm{ha}^{-1}\right)$} & \multicolumn{2}{|c|}{ Seed size $(g / 1000)$} & \multicolumn{2}{|c|}{ Harvest Index } & \multicolumn{2}{|c|}{ Grain yield $\left(\mathrm{kg} \mathrm{ha}^{-1}\right)$} \\
\hline & $\mathrm{BD}$ & $\mathrm{BK}$ & $\mathrm{BD}$ & $\mathrm{BK}$ & $\mathrm{BD}$ & $\mathrm{BK}$ & $\mathrm{BD}$ & $\mathrm{BK}$ \\
\hline Black Seeded & 7434 & 682 & 0.25 & 0.98 & 0.26 & 0.48 & 1966 & 413 \\
\hline Multi-Hued & 3781 & 2794 & 0.34 & 1.28 & 0.29 & 0.27 & 2916 & 692 \\
\hline Bio-Bio & 7507 & 2752 & 0.19 & 1.01 & 0.27 & 0.20 & 1983 & 559 \\
\hline Brightest BR & 8907 & 1994 & 0.30 & 1.16 & 0.37 & 0.24 & 2997 & 473 \\
\hline Red Head & 7230 & 598 & 1.00 & 1.04 & 0.27 & 0.30 & 2413 & 537 \\
\hline Cherry Vanilla & 8549 & 1064 & 1.11 & 1.14 & 0.33 & 0.24 & 2818 & 315 \\
\hline Inca Red & 3034 & 1582 & 0.45 & 1.03 & 0.10 & 0.16 & 317 & 217 \\
\hline Titicaca & 5580 & 955 & 0.28 & 1.10 & 0.56 & 0.32 & 3019 & 255 \\
\hline QQ74 & 7261 & 1414 & 0.29 & 1.20 & 0.41 & 0.50 & 2954 & 292 \\
\hline Puno & 9895 & 2500 & 0.34 & 1.28 & 0.31 & 0.32 & 2260 & 446 \\
\hline Ecuadorian & 2584 & 246 & 0.14 & 0.19 & 0.15 & 0.29 & 237 & 62 \\
\hline Mean & 7173 & 1443 & 0.42 & 1.03 & 0.30 & 0.30 & 2171 & 388 \\
\hline LSD (0.05) & \multicolumn{2}{|c|}{499.9} & \multicolumn{2}{|c|}{0.05} & \multicolumn{2}{|c|}{0.18} & \multicolumn{2}{|c|}{763.8} \\
\hline $\mathrm{CV} \%$ & \multicolumn{2}{|c|}{23.42} & \multicolumn{2}{|c|}{14.47} & \multicolumn{2}{|c|}{35.2} & \multicolumn{2}{|c|}{36.2} \\
\hline Variety $_{\mathrm{F} \text { Probability }}$ & \multicolumn{2}{|c|}{$<0.001$} & \multicolumn{2}{|c|}{$<0.001$} & \multicolumn{2}{|c|}{0.001} & \multicolumn{2}{|c|}{0.001} \\
\hline Site $_{\text {F Probability }}$ & \multicolumn{2}{|c|}{$<0.001$} & \multicolumn{2}{|c|}{$<0.001$} & \multicolumn{2}{|c|}{0.998} & \multicolumn{2}{|c|}{0.001} \\
\hline Variety x Site $_{F \text { Probability }}$ & \multicolumn{2}{|c|}{$<0.001$} & \multicolumn{2}{|c|}{$<0.001$} & \multicolumn{2}{|c|}{0.039} & \multicolumn{2}{|c|}{0.001} \\
\hline $\mathrm{SE} \pm$ & \multicolumn{2}{|c|}{247.3} & \multicolumn{2}{|c|}{0.026} & \multicolumn{2}{|c|}{0.034} & \multicolumn{2}{|c|}{117.9} \\
\hline
\end{tabular}

Seed size was significantly ( $\mathrm{p} \leq 0.001)$ larger at Bembeke (1.03 g/1000 seeds) than at Bunda ( $0.42 \mathrm{~g} / 1000$ seeds) (Table 6). 
Table 7. Number of days to maturity in quinoa varieties evaluated in six different sites of central Malawi during the 2015 irrigated season (May to August 2015) $\left(\mathrm{F}_{\text {prob }}=<0.001\right.$ for variety, $<0.001$ for sites, $<0.001$ for Variety $\mathrm{x}$ Site interaction; $\mathrm{SED}=0.699$ ).

\begin{tabular}{lccccccc}
\hline \multirow{2}{*}{ Variety } & \multicolumn{9}{c}{ Site/EPA } & \multicolumn{1}{c}{ Variety mean } \\
\cline { 2 - 6 } Bio-Bio & Chiluwa & Kalira & Malomo & Mwansambo & Nalunga & Nkhunga & 104 \\
Black Seeded & 94 & 120 & 108 & 121 & 106 & 88 & 105 \\
Brightest Brilliant & 99 & 120 & 108 & 121 & 106 & 89 & 104 \\
Rainbow & 94 & 120 & 108 & 121 & 106 & 89 & 88 \\
Cherry vanilla & 94 & 120 & 108 & 121 & 106 & 104 \\
Multi-Hued & 94 & 120 & 108 & 121 & 106 & 87 & 104 \\
Puno & 94 & 120 & 108 & 121 & 106 & 86 & 104 \\
QQ74 & 94 & 120 & 108 & 121 & 106 & 88 & 104 \\
Red Head & 94 & 120 & 108 & 121 & 106 & 86 & 104 \\
Titicaca & 94 & 120 & 108 & 121 & 106 & 89 & 105 \\
Site mean & 94 & 120 & 108 & 121 & 106 & 88 &
\end{tabular}

while in Malomo, BBR (4583 $\mathrm{kg} \mathrm{ha}^{-1}$ ), Bio-Bio (4375 $\left.\mathrm{kg} \mathrm{ha}^{-1}\right)$, Multi-Hued (4323 kg ha-1) and Cherry Vanilla (3984 $\left.\mathrm{kg} \mathrm{ha}^{-1}\right)$ were the highest yielding varieties.

The grain yield pattern was consistent across the six sites and genotypes tested in the subsequent year of 2015 (Figures 8 and 9 in the Appendix), with Nalunga, Malomo and Kalira 2 emerging as the best environments for quinoa production in Malawi. The significant variation across the environments was attributed to temperature, where the high-altitude sites, which were the best environments, experienced lower temperatures, within the range of 10 to $25^{\circ} \mathrm{C}$ (Jacobsen et al. 2003). The sites that had lower grain yields experienced average temperatures above $25^{\circ} \mathrm{C}(25$ to $28^{\circ} \mathrm{C}$ ) (Table 4). Higher temperatures lead to high flower abortion, which consequently reduce grain yields in quinoa (Garcia et al. 2015).

The environments showed strong differences in the manner in which they influenced the relative genotypic performance for grain yield (Figure 10 in the Appendix). The environmental variation expressed across the topographical range requires breeding and testing strategies structured to accommodate the effects of large $\mathrm{G} \times \mathrm{E}$ interactions.

\section{Rainfed quinoa performance at Bunda}

\section{Maturity period}

The genotypes physiologically matured and were ready for harvesting at 90days from sowing in the 2012/13seasonand at 75 days in the 2013/14 rainy season. While there were no significant differences in the days to maturity in either season ( $p>0.05)$,two genotypes, Black Seeded and Multi-Hued, matured relatively late (at 112 days) in the 2012/13 season, and Puno matured relatively early (at 64 days) in the 2013/14 season (Figure 11 in the Appendix). Rainfed crop production in Malawi occurs when temperatures are warmer and therefore accelerate plant growth. From the current results, quinoa matures earlier in Malawi than in regions where it is traditionally grown, where it takes 120 to 150 days to reach maturity. In drought-prone regions, early maturity is a trait that allows a variety to escape drought-related stresses. Early maturity would allow quinoa plants to cope with climate change impacts that 
Table 8. Grain yield $\left(\mathrm{kg} \mathrm{ha}^{-1}\right)$ of quinoa genotypes evaluated in six different sites of central Malawi during the 2015 irrigated season (May to August 2015) $\left(\mathrm{F}_{\mathrm{prob}}=<0.089\right.$ for variety, $<0.001$ for sites, $<0.967$ for Variety $\times$ Site interaction; $\mathrm{SED}=242 ; \mathrm{LSD}=477.5)$.

\begin{tabular}{|c|c|c|c|c|c|c|c|}
\hline \multirow{2}{*}{ Variety } & \multicolumn{6}{|c|}{ Site/EPA } & \multirow{2}{*}{ Variety mean } \\
\hline & Chiluwa & Kalira & Malomo & Mwansambo & Nalunga & Nkhunga & \\
\hline Bio-Bio & 1049 & 1646 & 2433 & 1477 & 3210 & 1413 & 2032 \\
\hline Black Seeded & 823 & 1852 & 2173 & 1364 & 3426 & 1335 & 1990 \\
\hline $\begin{array}{l}\text { Brightest Brilliant } \\
\text { Rainbow }\end{array}$ & 1255 & 1543 & 3614 & 2436 & 3992 & 1660 & 2641 \\
\hline Cherry Vanilla & 1276 & 2366 & 3056 & 1813 & 3056 & 1564 & 2312 \\
\hline Multi-Hued & 1132 & 1955 & 3184 & 1786 & 3272 & 1799 & 2376 \\
\hline Puno & 1121 & 1440 & 2536 & 1662 & 3251 & 1581 & 2107 \\
\hline QQ74 & 1091 & 2469 & 4311 & 1418 & 3652 & 1776 & 2717 \\
\hline RedHead & 1276 & 1440 & 2694 & 2163 & 3014 & 1317 & 2103 \\
\hline Titicaca & 1667 & 2469 & 2027 & 1560 & 3107 & 1715 & 2155 \\
\hline Site mean & 1188 & 1909 & 2892 & 1742 & 3331 & 1573 & \\
\hline
\end{tabular}

are affecting the region, such as prolonged dry spells or short rainy seasons (Mujica, 1988), with limited water availability for irrigation.

\section{Plant height and panicle length}

Plant height at physiological maturity significantly varied among the nine genotypes under rainfed conditions in Bunda. In the 2012/13 season, the plant heights $(\mathrm{p}<0.001)$ of most of the genotypes ranged from 88 to $131 \mathrm{~cm}$, with the exception of Ecuadorian $(12 \mathrm{~cm})$ and Inca Red $(20.40 \mathrm{~cm})$, which were far shorter than most genotypes evaluated. The Ecuadorian genotype was subsequently dropped in the 2013/14 season because too few seeds were available for a full experiment. In 2013/14, the plant height of the genotypes varied $(\mathrm{p}=0.023)$ from $67 \mathrm{~cm}$ to $95 \mathrm{~cm}$. The tallest genotypes were Brightest Brilliant Rainbow (BBR (95.41 $\mathrm{cm})$, Black Seeded (93.59 cm), Multi-Hued (87.1 $\mathrm{cm})$, Red Head $(87.04 \mathrm{~cm})$, QQ74 $(86.56 \mathrm{~cm})$ and Bio-Bio $(86.1 \mathrm{~cm})$. The shortest plants recorded were Cherry Vanilla $(80.42 \mathrm{~cm})$, Titicaca $(81.75$ $\mathrm{cm})$ and Puno $(66.66 \mathrm{~cm})$. Panicle length corresponded with plant height, where the longest panicles were recorded for BBR, Multi-Hued, Black Seeded, Cherry Vanilla, QQ74 and Bio-Bio (Table 9 and Figures 11 and 12 in the Appendix). Tall plants generally imply long panicles and high seed yields. Where leafy vegetables are the target, tall plants may also translate into more leaf production; however, this phenomenon needs to be studied when breeding for leaf production is the primary objective.

\section{Grain yield and its components}

Genotypes significantly varied in seed size (weight of 1000 seeds) in both seasons, 2012/13 and 2013/14 (Table 9 and Figures 12 part (d) and 13 part (d) in the Appendix).In 2012/13, the seed size ranged from $1.925 \mathrm{~g}$ to $2.625 \mathrm{~g}$ per 1000 seeds, with QQ74 seeds as the largest (2.625 g/1000 seeds), followed by Cherry Vanilla (2.45 g/1000 seeds), BBR (2.200 g/1000 seeds), and Titicaca (g/1000 seeds), while Rosa Junin, Ecuadorian and MultiHued had the lowest seed sizes of 1.925 g, 1.925 g and $2.000 \mathrm{~g}$, respectively, per 1000 seeds. In 2013/14, the seed size ranged from 2.08 to 3.168 g per 1000 seeds. The genotypes with larger seed sizes were Cherry Vanilla (3.168 g), Titicaca (2.7 g), Puno (2.77 g), QQ74 (2.65 g) and BBR (2.567 g), while Inca Red (2.29 g/1000 seeds) and Black Seeded ( $2.08 \mathrm{~g} / 1000$ seeds) had the smallest seeds. Seed sizes obtained in these studies were within the ranges obtained elsewhere (Yazar et al. 2015), suggesting the same quality of seed/grain obtained in the traditional production areas of quinoa.

The market for quinoa grain is reported to traditionally prefer varieties of large grains and cream white or appearing cream white when processed (cleaned or washed) and that can be prepared like rice. Small grain quinoa is generally used 
Table 9. The performance of quinoa genotypes planted at the Bunda college farm and grown under rainfed conditions during 2012/13 (rainfed experiments were conducted at the Bunda site only because Bembeke had logistical challenges).

\begin{tabular}{lcccccc}
\hline Varieties/lines & $\begin{array}{c}\text { Plant height } \\
(\mathrm{cm})\end{array}$ & $\begin{array}{c}\text { Panicle length } \\
(\mathrm{cm})\end{array}$ & $\begin{array}{c}\text { Biomass yield } \\
\left(\mathrm{kg} \mathrm{ha}^{-1}\right)\end{array}$ & $\begin{array}{c}\text { Seed weight } \\
(\mathrm{g} / 1000)\end{array}$ & $\begin{array}{c}\text { Harvest index } \\
\text { Grain yield } \\
\left(\mathrm{kg} \mathrm{ha}^{-1}\right)\end{array}$ \\
\hline Black Seeded & 67.3 & 59.7 & 3163 & 2.1 & 0.29 & 2050 \\
Multi-Hued & 74.7 & 60.4 & 3612 & 2.0 & 0.18 & 1603 \\
Bio-Bio & 68.3 & 62.3 & 2924 & 2.0 & 0.19 & 1446 \\
Brightest BR & 73.6 & 40.7 & 2644 & 2.2 & 0.23 & 1386 \\
Rosa Junin & 90.3 & 73.8 & 2494 & 1.9 & 0.15 & 891 \\
Red Head & 69.5 & 56.4 & 2184 & 2.2 & 0.14 & 789 \\
Cherry Vanilla & 73.8 & 52.0 & 2018 & 2.4 & 0.15 & 756 \\
Inca Red & 56.8 & 42.6 & 1042 & 2.1 & 0.26 & 665 \\
Titicaca & 69.6 & 47.0 & 2003 & 2.1 & 0.13 & 653 \\
QQ74 & 72.1 & 63.9 & 2052 & 2.6 & 0.11 & 566 \\
Puno & 65.0 & 41.5 & 1238 & 2.0 & 0.18 & 522 \\
Ecuadorian & 62.9 & 44.6 & 623 & 1.9 & 0.15 & 257 \\
F. Prob. & 0.001 & 0.001 & 0.001 & 0.0 & 0.002 & 0.001 \\
LSD (0.05) & 19.02 & 22.55 & 837.8 & 0.24 & 0.106 & 587 \\
SE \pm & 9.35 & 11.08 & 411.8 & 0.11 & 0.052 & 288 \\
\hline
\end{tabular}

to make flakes, flour and other products. The genotypes evaluated in this study represent all ranges of grain colours and sizes that, if released, could help meet most of the market preferences. Improving quinoa grain size can be accomplished by improving grain size uniformity in the panicle. A single panicle can contain three different grain sizes, depending on the genotype and on the proportion of hermaphroditic flowers (larger) and pistillate flowers (smaller) in the panicle (Bhargava et al., 2007).

Grain yield (Table 9 and Figures 13and14 in the Appendix) significantly varied $(\mathrm{p}<0.001)$ among the genotypes, with Black Seeded (2052 kg ha-1), Multi-Hued (1603 kg ha'-1), Bio-Bio (1446 kg ha-1) and BBR (1386 kg ha-1) being the high-yielding genotypes. Low-yielding genotypes under the rainy conditions were Ecuadorian $\left(257 \mathrm{~kg} \mathrm{ha}^{-1}\right)$ and Puno (522 kg ha-1). In the following 2013/14 rainy season, Black Seeded (1753 kg ha $\left.{ }^{-1}\right)$, Red Head (1495 kg ha'-1), Multi-Hued (1477 kg ha-1), BBR (1300 kg ha $\left.{ }^{-1}\right)$, Bio-Bio (1292 kg ha $\left.{ }^{-1}\right)$ and QQ74 (1202 $\mathrm{kg} \mathrm{ha}^{-1}$ ) had high yields. In terms of productivity, based on the harvest index, there were no significant differences $(p=0.065)$ in the $2012 / 13$ rainy season, while there were significant differences $(p=0.002)$ in the $2013 / 14$ rainy season. The harvest indices ranged from 0.25 to 0.43 . The genotypes with high harvest indices were Inca Red (0.43), Red Head (0.43), QQ74 (0.39), BBR (0.36), Black Seeded (0.35), Bio-Bio (0.33) and Multi-Hued (0.32).

The grain yield performance of these genotypes under rainfed conditions in Bunda demonstrated that quinoa production under rainfed conditions is possible, especially in environments similar to Bunda. The yields are comparable to those reported in regions where quinoa is traditionally grown. Mujica et al. (2001) reported yields of 2.28 and 3.96 tons/ha from genotypes selected for North America and Europe, such as Italy and Greece. Bonifacio (2003) reported yields of cultivars obtained in Bolivia that yielded close to 1.2 tons/ha in Altiplano and were considered higher yielders, yielding over the $700 \mathrm{~kg} \mathrm{ha}^{-1}$ that farmers growing traditional varieties obtained. On the other hand, trials that were conducted along the Peruvian coast showed that grain yields of 6 tons/ha are possible when a fertilization and irrigation system is adopted.

The harvest index (HI) did not significantly vary ( $p=0.065 ; 0.13$ to 0.29 ) in $2012 / 13$ but significantly varied ( $p=0.002 ; 0.26$ to 0.43 ) in the 2013/14 rainfed evaluation among the genotypes (Figures 13-part $\mathrm{b}$ and 14 part b). The HI trait measures photosyn- 
thetic capability and the rate of translocation of photosynthates to the seeds. In addition to genotype, the HI is reported to be influenced by both environment and farming practices (Bertero and Ruiz, 2010). Quinoa germplasm studies in Bolivia showed harvest index variation of 0.06 to 0.87 . The lower values were typical of Inter-Andean valleys ecotype quinoa varieties, characterized by their tall height and branching patterns (Rojas et al., 2000). High HI values are preferred when selecting for high grain yield; on the other hand, low HI values may be a good indicator of better genotypes for leafy vegetable production, but this phenomenon needs to be investigated.

\section{Pests and diseases and challenges}

No significant infestation of pests or disease incidences was observed on the genotypes evaluated. However, the insect pests observed included cutworms and aphids. Molds were also observed growing on some stems that weathered out from stem tips during the vegetative phase.

From other studies (Kanyumbu, 2015, Saindi, 2015), the molds become more devastating if the same piece of land is used continuously for quinoa growing without rotation. The literature reports that the majority of diseases affecting quinoa crops are due to fungi, while bacteria, nematodes and viruses are also a problem on a smaller scale. The incidence and severity vary according to the variety, phonological stage and environmental conditions (Tapia et al., 1979). The most significant and well-known disease at a global level is downy mildew, of which the most important factor is the environment, with relative humidity $(>80 \%)$ and cool temperatures particularly being the most favorable.

Other challenges encountered were poor establishment of the crop during the rainy season, as some plants were damaged by heavy storms at post emergence. Lodging of plants was also observed mainly under rainfed production in some genotypes (Mabedi, 2015; Maliro and Guwela
2015). While early planting gave better crop establishment, the seeds also matured early, before cessation of rains, which led to sprouting of seeds while in the field. Sprouting of the seeds in the field prompts harvesting before the panicles dry, calling for extra care before threshing (Mabedi, 2015; Maliro and Guwela 2015).

\section{Strategies for the promotion of quinoa in Malawi}

Quinoa production can help to reduce the problem of malnutrition in Malawi because the grain has all nine amino acids and is gluten and cholesterol free compared with common cereals. To promote production and utilization of the crop, a value chain approach is believed to provide the strategy that can make the highest impact in the Malawi society within a short period. Strategies to promote quinoa production and utilization in Malawi have so far included release of the currently best performing varieties for commercialization and training of rural households about the nutritive value of quinoa and processing for consumption.

\section{Development of a seed system: Variety release for farmers' use}

Establishment of a seed system to ensure the availability of high-quality seeds of the best performing varieties is the primary strategy to promote quinoa in Malawi. One of the accomplishments of the current quinoa research in Malawi has been the approval of seven genotypes as varieties by the Agricultural Technology Clearing Committee (ATCC) of the Ministry of Agriculture, Irrigation and Water Development (MoAIWD). The data generated from the agronomic experiments from 2014 to 2016 demonstrated that quinoa production in Malawi is possible. The ATCC in August 2017 approved the release of seven varieties of quinoa on the basis of their consistent and outstanding performance in the various environments tested, with grain yields ranging from 1.2 tons/ha to 4.0 tons/ha: Brightest Brilliant Rainbow (BBR), BioBio, Black Seeded, Cherry Vanilla, Multi-Hued, 
Table 10. Main plant growth and grain yield traits of the recommended varieties for release in Malawi - based on the local study results.

\begin{tabular}{|c|c|c|c|c|c|c|c|c|}
\hline \multicolumn{2}{|c|}{ Name varieties } & \multirow[t]{2}{*}{$\begin{array}{l}\text { Proposed } \\
\text { brand } \\
\text { name }\end{array}$} & \multirow{2}{*}{$\begin{array}{l}\text { Panicle colour at maturity } \\
\begin{array}{l}\text { Panicle are orange to } \\
\text { green- yellow }\end{array}\end{array}$} & \multirow{2}{*}{$\begin{array}{l}\text { Seed colour } \\
\text { Cream }\end{array}$} & \multirow{2}{*}{$\begin{array}{l}\begin{array}{l}\text { Number } \\
\text { of days to } \\
\text { Maturity }\end{array} \\
80 \text { to } 120\end{array}$} & \multirow{2}{*}{$\begin{array}{l}\text { Plant height } \\
\text { at maturity }\end{array}$} & \multirow{2}{*}{$\begin{array}{l}\begin{array}{l}\text { Panicle } \\
\text { length at } \\
\text { maturity }\end{array} \\
20 \text { to } 45\end{array}$} & \multirow{2}{*}{  } \\
\hline 1 & $\begin{array}{l}\text { Brightest } \\
\text { Brilliant } \\
\text { Rainbow }\end{array}$ & & & & & & & \\
\hline 2 & $\begin{array}{l}\text { Black } \\
\text { seeded }\end{array}$ & & $\begin{array}{l}\text { Panicle colours range } \\
\text { from Purple,pink, green to } \\
\text { Yellowish }\end{array}$ & $\begin{array}{l}\text { Multi-colour: } \\
\text { Cream white, } \\
\text { Brown, } \\
\text { purple,pink } \\
\text { Gray, }\end{array}$ & 100 to 120 & 80 to 90 & 15 to 40 & 3,500 \\
\hline 3 & Biobio & & $\begin{array}{l}\text { Purple panicles, Seeds } \\
\text { (purple), }\end{array}$ & Cream white & 90 to 120 & 80 to 100 & 15 to 40 & 3,200 \\
\hline 4 & $\begin{array}{l}\text { Cherry } \\
\text { vanilla }\end{array}$ & & $\begin{array}{l}\text { Panicle colours are pinkish } \\
\text { to greenish-orange }\end{array}$ & Cream white & 80 to 120 & 80 to 95 & 15 to 35 & 3,000 \\
\hline 5 & Multihued & & $\begin{array}{l}\text { Panicles are pink to green- } \\
\text { yellow }\end{array}$ & Cream white & 80 to 120 & 80 to 90 & 30 to 50 & 3,200 \\
\hline 6 & QQ74 & & $\begin{array}{l}\text { Panicles are orange } \\
\text { coloured }\end{array}$ & Cream & 80 to 120 & 80 to 110 & 20 to 45 & 3,600 \\
\hline 7 & Titicaca & & $\begin{array}{l}\text { Panicles are Orange to } \\
\text { green-yellow }\end{array}$ & Cream white & 80 to 120 & 70 to 75 & 15 to 35 & 3,000 \\
\hline
\end{tabular}

QQ74 and Titicaca. To popularize the varieties, the research team is currently working with the MoAIWD's Seed Services Unit on developing standards for the seed multiplication and certification process.

Quinoa in nutritional programs for rural com$\underline{\text { munities }}$

The Lilongwe University of Agriculture and Natural Resources (LUANAR) in collaboration with Total Land Care (TLC) under a component of the 'Management for Adaptation to Climate Change II (MACC II)' project (2014 to 2019) in the Nkhotakota, Salima, Ntchisi, Lilongwe and Dowa districts, started to train some of the communities on various food recipes for consumption. Some of the processing activities that farmers are engaged in with the support from the TLC include milling the quinoa grain with maize and peanuts to produce flour used in making porridge (a local Likuni Phala) to feed young children. Increased intake of this recipe of porridge by children less than five years old is expected to help reduce stunting because of the high nutritional value of quinoa grain to show the farmers on how to grow quinoa crop.
The MACC II project was expected to contribute to increasing access to high nutritive food products among under five-year-old children and expectant and lactating mothers in the impact areas. The project therefore included promotion of quinoa household utilization in the farming communities of two sites (Nalunga EPA in the Dowa district and Nkhunga EPA in the Nkhotakota district) where the genotypes were evaluated. Under this objective, the activities of promoting quinoa therefore included the distribution of seed (20 to $50 \mathrm{~g} /$ household) to 120 households annually, the training of two women's groups $(10+$ women in Nalunga EPA and 15 women in Nkhunga EPA) on the processing of quinoa grain (specifically washing to remove saponin) and development of local recipes into products (such as nsima, cakes, and beverages). During the 2014/15 winter cropping season, one village in Nalunga EPA where 28 farmers grew quinoa in plots of various sizes produced more than 1,000 $\mathrm{kg}$ (1 ton) of quinoa grain under irrigation, which demonstrated the high interest that many of the farmers have to grow the crop. The communities expressed preference for the quinoa leaves as a vegetable over Amaranthus leaves due to, in their opinion, better taste. This calls for the 
quinoa research in Malawi to include objectives of selecting for varieties suitable for use as leafy vegetables as well.

Similar out-scaling and training activities were implemented in the Zomba district in the southern region of the country through the Sitima Catholic Parish, where $120+$ households were given quinoa seed for production and utilization. Women from these households were also trained on how to process quinoa grain for home consumption through various recipes, i.e., porridge for the children under five.

The AquaAid organization, which has established schools and feeding programs at Sitima in the Zomba district and at Lunzu in the Blantyre district, has been provided with quinoa seed for production since 2014 . The grain produced at these centers is milled and incorporated into the diets of their school children and staff.

Stakeholder meetings and field days

Annual meetings and field days that included farmers, traditional leaders, extension workers, and other stakeholders were organized from 2014 to 2017 to familiarize them and to help them appreciate the quinoa crop plants and food products prepared from the grain.

Dissemination at National agricultural and trade fairs

Since 2014, LUANAR has been educating the Malawian public about quinoa's potential contribution to the national food and nutritional security through displays of quinoa grain samples and information at agricultural and trade fairs that take place annually in the country.

Materials such as banners, sign boards, t-shirts and caps with information about quinoa were also freely distributed to farmers during the media event that took place in 2016 and triggered interest and inquiries from the public about quinoa.

\section{$\underline{\text { Media }}$}

Radio and television stations can be very effective tools in promoting a new crop in a country. Since quinoa was introduced in Malawi, the media has and will continue to play an important role in educating the Malawian public about quinoa, as the majority of smallholder farmers like to listen to local radio stations. Radio stations that participated in educating the public about quinoa included the Malawi Broadcasting Corporation $(\mathrm{MBC})$ and the Zodiac Broadcasting Corporation (ZBS) radio stations and television stations.

\section{Conclusions and Recommendations}

Quinoa plants can grow up to $130 \mathrm{~cm}$, and grain yields up to 4 tons/ha are achievable under irrigated conditions. Quinoa crops can be grown across different ecologies ranging from warm to cool areas, as demonstrated in central Malawi ecologies. However, the maturity period varied (ranging from 88 to 121 days) and was delayed when moving from warm sites (88 days in Nkhunga and 94 days in Chiluwa EPAs) to cooler sites (121 days in Nalunga and 120 days in Kalira2 EPAs) in the trials. At relative mid-altitude, maturity took 106 days in Mwansambo and 108 days in Malomo.

The mean grain yields ranged from $1,188 \mathrm{~kg} \mathrm{ha}^{-1}$ to $3,331 \mathrm{~kg} \mathrm{ha}^{-1}$ across sites, while the average grain yield performance of individual varieties ranged from $1,990 \mathrm{~kg} \mathrm{ha}^{-1}$ to $2,717 \mathrm{~kg} \mathrm{ha}^{-1}$. Among the varieties, QQ74 (2,717 $\left.\mathrm{kg} \mathrm{ha}^{-1}\right)$ and Brightest Brilliant Rainbow $\left(2,640 \mathrm{~kg} \mathrm{ha}^{-1}\right)$ had the highest overall yields, and Multi-Hued (2,376 $\left.\mathrm{kg} \mathrm{ha}^{-1}\right)$ and Cherry Vanilla $\left(2,312 \mathrm{~kg} \mathrm{ha}^{-1}\right)$ had overall intermediate yields. The overall yields of the other varieties were $2,155 \mathrm{~kg} \mathrm{ha}^{-1}$ for Titicaca, 2,107 $\mathrm{kg} \mathrm{ha}^{-1}$ for Puno, 2,103 kg ha-1 for Red Head, 2,032 kg ha-1 for Bio-Bio and 1,990 $\mathrm{kg} \mathrm{ha}^{-1}$ for Black Seeded.

Site-specific high grain-yielding varieties were Brightest Brilliant Rainbow (BBR) (3,992 $\left.\mathrm{kg} \mathrm{ha}^{-1}\right)$, QQ74 (3,652 $\left.\mathrm{kg} \mathrm{ha}^{-1}\right)$, Black Seeded (3,426 $\left.\mathrm{kg} \mathrm{ha}^{-1}\right)$, 
Multi-Hued (3,272 $\left.\mathrm{kg} \mathrm{ha}^{-1}\right)$ and Puno (3,251 $\left.\mathrm{kg} \mathrm{ha}^{-1}\right)$ for Nalunga EPA; QQ74 (4,311 $\left.\mathrm{kg} \mathrm{ha}^{-1}\right), \operatorname{BBR}(3,331$ $\left.\mathrm{kg} \mathrm{ha}^{-1}\right)$, Multi-Hued $\left(3,184 \mathrm{~kg} \mathrm{ha}^{-1}\right)$ and Cherry Vanilla (3,056 $\left.\mathrm{kg} \mathrm{ha}^{-1}\right)$ for Malomo EPA; QQ74 and Titicaca $\left(2,469 \mathrm{~kg} \mathrm{ha}^{-1}\right)$, Cherry Vanilla (2,366 $\left.\mathrm{kg} \mathrm{ha}^{-1}\right)$ and Multi-Hued (1,955 $\left.\mathrm{kg} \mathrm{ha}^{-1}\right)$ for Kalira EPA; BBR (2,436 kg ha-1), Red Head (2,163 $\left.\mathrm{kg} \mathrm{ha}^{-1}\right)$, Cherry Vanilla (1,813 $\left.\mathrm{kg} \mathrm{ha}^{-1}\right)$ and Multi-Hued (1,786 $\left.\mathrm{kg} \mathrm{ha}^{-1}\right)$ for Mwansambo EPA; Multi-Hued (1,799 $\left.\mathrm{kg} \mathrm{ha}^{-1}\right)$, QQ74 (1,776 kg ha-1 $)$ and Titicaca $(1,715 \mathrm{~kg}$ $\left.\mathrm{ha}^{-1}\right)$ for Nkhunga EPA; and Titicaca $\left(1,667 \mathrm{~kg} \mathrm{ha}^{-1}\right)$, Cherry Vanilla and Red Head $\left(1,276 \mathrm{~kg} \mathrm{ha}^{-1}\right)$ and $\operatorname{BBR}\left(1,255 \mathrm{~kg} \mathrm{ha}^{-1}\right)$ for Chiluwa EPA.

The genotypes of QQ74, Brightest Brilliant Rainbow, Multi-Hued, Cherry Vanilla, Bio-Bio, Titicaca and Black Seeded were released as varieties to be grown by farmers in Malawi (Table 10 in the Appendix).

Several strategies, including the release of quinoa varieties, seed distribution to interested farmers and trainings on the utilization of the grain, have helped to start promotion of quinoa production and utilization in Malawi. However, only a small section of the population is aware of the potential of quinoa's contribution to food and nutritional security. Therefore, the next phase should include promotion of seed multiplication and certification of the released varieties and education of the farmers and the general public to promote its production and utilization.

Research on quinoa should continue with the evaluation of more genotypes to meet the diverse stresses (droughts, pests and diseases) of the different environments of the country. During the introduction phase of the crop, farmers explored the use of the leaves as a vegetable; hence, research should also consider the selection of varieties for leaf production.

There is a need for a value chain approach in the promotion of quinoa production and utilization, hence the need for quinoa marketing considerations.

\section{Acknowledgments}

Financial support for the experiments in the Total Land Care impact districts was provided by the Royal Norwegian Embassy in Lilongwe through the MACC II project. The early evaluation trials were conducted with support from Washington State University and Robert Leong. The Department of Crop and Soil Sciences of LUANAR hosted all the trials conducted at Bunda site and supported all experiments conducted by undergraduate students that contributed to some of the results reported in this paper.

\section{Resumen}

M.F.A. Maliro, y A.L. Njala. 2019. Desempeño agronómico y estrategias de promoción de la Quinua (Chenopodium quinoa Willd) en Malawi. Cien. Agr. 46(2): 82-99. La quinua (Chenopodium quinoa Willd) tiene el potencial de contribuir a la seguridad alimentaria y nutricional de Malawi mediante la adaptación a las sequías que se han vuelto frecuentes debido al cambio climático. En 2012 se introdujeron once genotipos de quinua y se evaluó el crecimiento y rendimiento de las plantas en diferentes ambientes de las regiones central y meridional de Malawi para determinar el potencial de producción de quinua en el país. Los primeros ensayos se llevaron a cabo en Bunda en Lilongwe y Bembeke en Dedza en 2012 en condiciones de riego. Los ensayos en condiciones de temporal se llevaron a cabo en el sitio de Bunda en las temporadas de cosecha 2012/13 y 2014/15. La evaluación de trece genotipos prometedores en condiciones de riego (2014 a 2015) se extendió a seis áreas de planificación de extensiones, incluyendo Chiluwa en Salima y Nkhunga (Nkhotakota) como ambientes cálidos, Mwansambo (Nkhotakota) como un ambiente levemente cálido, Malomo (Ntchisi) como un 
ambiente ligeramente frío, y Kalira 2 (Ntchisi) y Nalunga (Dowa) como ambientes frescos. Los genotipos se presentaron en diseños de bloques completamente aleatorizados con cuatro réplicas. El período de maduración de los genotipos fue temprano en los sitios cálidos (88 días en Nkhunga y 94 días en Chiluwa) y retrasado en los sitios más fríos (121 días en Nalunga y 120 días en Kalira). Sobre la base del genotipo y de los resultados específicos del sitio, se obtuvieron los rendimientos de grano más altos para Arco Iris Brillante Más Brillante (BBR) (3.992 kg ha$\left.{ }^{1}\right)$, QQ74 (3.652 kg ha-1), Semilla Negra (3.426 kg ha-1), Multi-Hued (3.272 kg ha-1) y Puno (3.251 kg ha' ${ }^{-1}$ en Nalunga y en QQ74 (4.311 $\left.\mathrm{kg} \mathrm{ha}^{-1}\right)$, BBR (3.331 kg ha-1), Multi-Hued (3.184 $\mathrm{kg} \mathrm{ha}^{-1}$ ) y Cherry Vanilla $\left(3.056 \mathrm{~kg} \mathrm{ha}^{-1}\right)$ en Malomo. Los rendimientos más bajos obtenidos fueron de Cherry Vanilla, Red Head (1.276 $\left.\mathrm{kg} \mathrm{ha}^{-1}\right)$ y BBR $\left(1.255 \mathrm{~kg} \mathrm{ha}^{-1}\right)$ en Chiluwa. La producción de quinua es posible en Malawi. Los genotipos QQ74, BBR, Multi-Hued, Cherry Vanilla, Bio-Bio, Titicaca y Black Seeded han sido liberados para su producción comercial. La participación de organizaciones gubernamentales y no gubernamentales centradas en los sistemas de semillas, el procesamiento y la utilización puede ayudar a integrar la quinua en los sistemas alimentarios de Malawi.

Palabras clave: Adaptación, agricultores, condiciones de riego, condiciones de temporal, quinua.

\section{References}

[AAFRD] Alberta Agriculture, Food and Rural Development. 2005. Quinoa - The next Cinderella crop for Alberta? A report by Alberta Agriculture, Food and Rural Development (AAFRD). Available from: http://www1.agric.gov. ab.ca/\$department/deptdocs.nsf/all/afu9961.

Adams, S.R., K.E. Cockshull and C.R.J. Cave, 2001. Effect of Temperature on the Growth and Development of Tomato Fruits. Annals of Botany, 88: 869-877. Doi:10.1006/anbo.2001.1524

Adolf, V.I., Shabala, S., Andersen, M.N., Razzaghi, F., Jacobsen, S.-E. 2012. Varietal differences of quinoa's tolerance to saline conditions. Plant Soil 357:117-129.

Aluwi, N., Gu, B-J., Dhumal, G., Medina-Meza, I.G., Murphy, K.M., Ganjyal, G. 2016. Impacts of scarification and degermination on the expansion characteristics of select quinoa varieties during extrusion processing. J. of Food Sci. (published on-line 25 Oct 2016). DOI: 10.1111/17503841.13512

Babatunde, R.O., Olungunju, F.I., Fakayode, S.B., Sola-Ojo, F.E. 2011. Prevalence and determinants of malnutrition among under five children of farming households in Kwara State, Nigeria. J.
Agric. Sci. 3:173-181. doi:10.5539/jas.v3n3p173

Bazile, D., Jacobsen, S-E., Vernaiu, A. 2016. The global expansion of quinoa: Trends and limits. Frontiers in Plant Sci. 7: 622. DOI: 10.3389/ fpls.2016.00622

Bhargava, A., Shukla, S., Rajan, S., Ohri, D. 2007. Genetic diversity for morphological and quality traits in quinoa (Chenopodium quinoaWilld.) germplasm. Genet. Res. \&CropEvol. 54: 167173. DOI 10.1007/s10722-005-3011-0

Bertero, H. D. and Ruiz, R. A. (2010). Reproductive Partitioning in Sea level quinoa D (Chenopodium quinoa Wild.) Cultivars Field Crops Res.60: 231243.

[FAO] Food and Agriculture Organization of the United Nations. 2012. Economic growth is necessary but not sufficient to accelerate reduction of hunger and malnutrition. Rome: FAO.

[FAO] Food and Agriculture Organization of the United Nations. 2012. Master plan for the International Year of Quinoa - a future sown thousands of years ago. Available from: http://www. fao.org/fileadmin/templates/aiq2013/res/en/master_plan.pdfJuly 2013.

Garcia G. A., Dreccer M. F., Miralles D. J., Serrago R. A. (2015). High night temperatures during grain number determination reduce wheat 
and barley grain yield: a field study. Glob. Change Biol.21 4153-4164. 10.1111/gcb.13009 [PubMed] [CrossRef] [Google Scholar]

Garcia, M. 2003. Agroclimatic study and drought resistance analysis of Quinoa for an irrigation strategy in the Bolivian Altiplano. Ph.D. dissertation. Dissertationes de Agricultura $\mathrm{N}^{\circ}$ 556. Fac. of Agr. and Applied Biol. Sciences, K.U.Leuven, Belgium.

Jacobsen, S.-E., Stølen, O. 1993. Quinoa morphology, phenology and prospects for its production as a new crop in Europe. Eur. J. Agron.2:19-29.

Jacobsen S. E. and Mujica, A. 2003. The worldwide potential for quinoa (ChenopodiumquinoaWilld.). Food Reviews Int. 19:167-177.

Jacobsen, S. E., Mujica, A. andJensen, C.R. 2003. The resistance of quinoa (Chenopodiumquino$a$ Willd.) to adverse abiotic factors. Food Reviews Int. 19: 99-109.

Jacobsen S. E., Monteros, C., Corcuera, L.J., Bravo, L.A., Christiansen, J.L., Mujica, A. 2007. Frost resistance mechanisms in quinoa (ChenopodiumquinoaWilld.). Eur. J. Agron.26:471-475.

Jayne, T.S., Yamano, T., Weber, M.T., Tschirley, D., Benfica, R., Chapoto, A. 2003. Smallholder income and land distribution in Africa: implications for poverty reduction strategies. Food Policy 28:253-275. doi:10.1016/S03069192(03)00046-0

Jenner, C.F. 1991. Effects of exposure of wheat ears to high temperature on dry matter accumulation and carbohydrate metabolism in the grain of two cultivars. I. Immediate response. Aust. J. Plant Physiol.18: 165-177.

Kanyumbu, A.F. 2015. Grain yield and quality traits of quinoa (Chenopodium quinoa Willd) in response to fertilizer application. A project report submitted in partial fulfillment of the requirements for Bachelor of Science Degree in Agronomy, Faculty of Agriculture, Lilongwe University of Agriculture and Natural Resources (LUANAR), Bunda Campus, Lilongwe.

Koziol, M.J. 1992. Chemical composition and nutritional evaluation of quinoa (Chenopodium quinoa Willd.). J Food Comp Anal 5(1):35-68.
Kowalski, R.J., Medina-Meza, I.G., Thapa, B.B., Murphy,K.M., Ganjyal, G.M. 2016. Extrusion processing characteristics of quinoa (Chenopodium quinoa Willd.) var. Cherry Vanilla. J. of Cereal Sci. 70: 91-98.

Mabedi, F. 2015. Plant growth and grain yield of quinoa (Chenopodium quinoa Willd) in response to time of planting under rainfed conditions. A project report submitted in partial fulfillment of the requirements for Bachelor of Science Degree in Agronomy, Faculty of Agriculture, Lilongwe University of Agriculture and Natural Resources (LUANAR), Bunda Campus, Lilongwe.

Maliro, M.F.A., Guwela, V.F., Nyaika, J. and Murphy, K.M. 2017. Preliminary Studies of the Performance of Quinoa (Chenopodiumquino$a$ Willd.) Genotypes under Irrigated and Rainfed Conditions of Central Malawi. Front. Plant Sci. 8:227. doi: 10.3389/fpls.2017.00227

Maliro, M.F.A. and Guwela, V. 2015. Quinoa breeding in Africa: History, Goals, and Progress. In: Quinoa: Improvement and Sustainable Production, K.M. Murphy and J.G. Matanguihan, (eds.), Wiley-Blackwell. Hoboken, New Jersey, USA.

Murphy, K.M., Bazile, D., Kellogg, J., Rahmanian, M. 2016. Development of a worldwide consortium on evolutionary participatory breeding in quinoa. Frontiers in Plant Sci. 7: 608.

Oelke, E.A., Putnam, D.H., Teynor, T.M., and Oplinger, E.S. 1992. Quinoa. Alternative Field Crops Manual University of Wisconsin-Extension. Available online athttp://www.hort.purdue. edu/newcrop/afcm/quinoa.html (accessed March 27, 2014)

Oyoo, M.E., Githiri, S.M., Ayiecho, P.O. 2010. Performance of some quinoa (Chenopodium quinoa Willd.) genotypes in Kenya. S. Afr. J. Plant \& Soil 27:2.

Peterson, A, and Murphy, K.M. 2014. Quinoa in the USA and Canada. In: The State of the World's Quinoa, D. Bazile (ed.), Food and Agriculture Organization, Rome, Italy.

Peterson, A.J., Jacobsen, S.-E., Bonifacio, A., Murphy, K.M. 2015. A crossing method for quinoa (Chenopodium quinoa). Sustainability 7: 3230-3243. 
Peterson, A., and Murphy, K.M. 2015a. Tolerance of lowland quinoa cultivars to sodium chloride and sodium sulfate salinity. Crop Sci. 55:331-338.

Peterson, A., and Murphy, K.M. 2015b. Quinoa Cultivation for Temperate North America: Considerations and Areas for Investigation. In: Quinoa: Improvement and Sustainable Production, K.M. Murphy and J.G. Matanguihan, (eds.), WileyBlackwell. Hoboken, New Jersey, USA.

Rojas, W., Barriga, P., Figueroa, H. 2000. Multivariate analysis of the genetic diversity of Bolivian quinoa germplasm. PGR Newsletter 122:16-23.

Ruiz, K.B., Aloisi, I., Del Duca, S., Canelo, V., Torrigiani, P., Silva, H., Biondi, S. 2016. Salares versus coastal ecotypes of quinoa: Salinity responses in Chilean landraces from contrasting habitats. Plant Phys. and Biochem.101: 1-13.

Schlick, G. and Bubenheim, D.L. 1993. Quinoa: An Emerging "New" Crop with Potential for CELSS. TechnicalPaper 3422. NASA. California. USA.

Sun, Y., Liu, F., Bendevis, M., Shabala, S., Jacobsen, S.-E. 2014. Sensitivity of two quinoa (ChenopodiumquinoaWilld.) varieties to progressive drought stress. J. of Agron. and Crop Sci. 200: 12-23.
[UN] United Nations. 2012. United Nations Resolution on the declaration of the IYQ 2013. A resolution adopted by General Assembly - A/ RES/66/221 in March 2012. Accessed at http:// www.un-ngls.org/IMG/pdf/IYQ.pdf, July 2013.

Walters, H., Carpenter-Boggs, L., Desta, K., Yan, L., Matanguihan, G.J., Murphy,K.M. 2016. Effect of irrigation, intercrop and cultivar on agronomic and nutritional characteristics of quinoa. Agroecology and Sust. Food Syst. 40: 783-803.

Wu, G., Murphy, K.M., Morris, C. 2014. Evaluation of texture differences among varieties of cooked quinoa. J. Food Sci. 79(11): S2337-S2345.

Wu, G., Peterson, A.J., Morris, C.F., Murphy,K.M. 2016. Quinoa seed quality response to sodium chloride and sodium sulfate salinity. Frontiers in Plant Sci. 7: 790.

Yazar A., Ince Kaya Ç, Sezen S. M., S. Tekin. 2015. Quinoa Experimentation and Production in Turkey, Chapter 5.15 in State of the Art Report of Quinoa in the World in 2013 by FAO \& CIRAD. 2015, by D. Bazile, D. Bertero\& C. Nieto, eds. Rome. 